\title{
POTENSI PEMBENTUKAN KERAK PADA INSTALASI DESALINASI NUKLIR MED DENGAN AIR UMPAN DARI TELUK MANGGRIS
}

\section{POTENTIAL OF SCALE FORMATION IN MED NUCLEAR DESALINATION PLANT WITH FEED WATER OF MANGGRIS GULF}

\author{
Siti Alimah dan Djati H.Salimy \\ Pusat Kajian Sistem Energi Nuklir (PKSEN) - BATAN \\ JI. Kuningan Barat, Mampang Prapatan, Jakarta, 12710 Telp/ Fax : (021) 5204243 \\ E-mail : alimahs@batan.go.id, djatihs@batan.go.id
}

\begin{abstract}
Abstrak
Pada tahun 2025 diperkirakan terjadi defisit kebutuhan air bersih penduduk Pulau Bangka, dan jika diasumsi sekitar $30 \%$ air bersih untuk penduduk dan fasilitas PLTN dipasok dari instalasi desalinasi MED (Multi-Effect Distillation) dengan energi panas nuklir, maka kapasitas produksi $90.000 \mathrm{~m}^{3} /$ hari. Salah satu permasalahan dalam instalasi desalinasi thermal adalah pembentukan kerak dalam permukaan perpindahan panas. Pembentukan kerak dalam instalasi desalinasi MED disebabkan oleh deposisi garam inorganik seperti kalsium karbonat, kalsium sulfat dan magnesium hidroksida. Kerak pada permukaan perpindahan panas dapat menurunkan laju perpindahan panas, yang akan berimplikasi pada penurunan kinerja dan efisiensi proses. Tujuan studi adalah menganalisis potensi pembentukan kerak dalam instalasi desalinasi MED, dengan air umpan dari Teluk Manggris. Metode yang digunakan adalah kajian literatur dan analisis berdasar perhitungan. Hasil studi menunjukkan bahwa terdapat potensi timbulnya kerak yang disebabkan oleh $\mathrm{CaSO}_{4}$ yang diindikasikan dengan positifnya harga indeks pengerakan (SI) sebesar 23,408. Potensi timbulnya kerak $\mathrm{CaCO}_{3}$ tidak ada, karena diperoleh harga LSI negatif dengan nilai $-0,63$. Namun air potensial bersifat korosif sehingga pertimbangan dalam pemilihan bahan alat perlu dilakukan. Selain itu juga terdapat potensi terbentuknya kerak $\mathrm{Mg}(\mathrm{OH})_{2}$.
\end{abstract}

Kata Kunci : desalinasi nuklir, air bersih, kerak, MED, Teluk Manggris.

\begin{abstract}
At the year of 2025 is estimated suffer a deficit of the need of fresh water in Bangka Island, and if assumed that the need of $30 \%$ fresh water of Bangka Island peoples and for supporting NPP's operation, can be supplied by nuclear desalination of MED (Multi-Effect Distillation) process, so the production capacity $90,000 \mathrm{~m} 3 /$ day. One of the problems in thermal desalination installation is scale formation in heat transfer surfaces. Scale formation in the MED desalination plant caused by the deposition of inorganic salts such as calcium carbonate, calcium sulfate and magnesium hydroxide. The scale on the surface of the heat transfer can reduce the flow of heat transfer, which will have implications for the decline in the performance and efficiency of the process. The purpose of the study was to analyze the potential of scale formation in the MED desalination plant, that utilize the feed water of Manggris Bay. The method used is literature assessment and analysis based on the calculation. The result study shows that there is potential for scale caused by $\mathrm{CaSO} 4$ which is indicated by positive value (23.408) of scaling index. There is no potential of scale formation caused by $\mathrm{CaCO} 3$, because resulted the negative value of LSI $(-0.63)$. However water will be potentially corrosive so that it becomes a consideration in equipment material selection. In addition there are also the potential of the scale formation caused by $\mathrm{Mg}(\mathrm{OH}) 2$.
\end{abstract}


Key Words : nuclear desalination, fresh water, scale, MED, Manggris Bay.

Diterima (recieved) : 15 Mei 2016, Direvisi (Revised) : 03 Oktober 2016, Disetujui

(Accepted) : 27 November 2016

\section{PENDAHULUAN}

Dari studi yang telah dilakukan BATAN, Pulau Bangka di Provinsi Kepulauan Bangka Belitung (Babel) merupakan salah satu calon tapak potensial PLTN di Indonesia ${ }^{1)}$. Guna memenuhi keperluan air pendingin reaktor PLTN, diperlukan air dengan spesifikasi tertentu, diantaranya TDS (total padatan terlarut) sekitar $1 \mathrm{ppm}^{2}$ ). Sementara itu air laut dari Teluk Manggris di pulau Bangka mempunyai TDS $32804 \mathrm{ppm}^{3)}$, sehingga diperlukan proses desalinasi untuk penyediaan air pendingin reaktor. Energi panas untuk proses desalinasi dapat berasal dari PLTN4).

Studi terdahulu menunjukkan bahwa Pulau Bangka pada tahun 2025 diperkirakan akan mengalami defisit air bersih sebesar $285.105 \mathrm{~m}^{3} / \mathrm{hari}^{3)}$. Untuk memenuhi kebutuhan air bersih sebagai pendukung operasi PLTN 1000 MWe sebesar $2750 \mathrm{~m}^{3}$ /hari5), dan sekaligus menyumbang kebutuhan $30 \%$ air bersih untuk kehidupan sehari-hari, maka kapasitas produksi air bersih instalasi desalinasi dengan energi panas nuklir adalah $90.000 \mathrm{~m}^{3} / \mathrm{hari}$.

Teknologi desalinasi MED (MultipleEffect Distillation) yang beroperasi pada temperatur rendah merupakan proses desalinasi thermal yang paling efisien saat ini dan penggunaan TVC (Thermal Vapor Compression) akan meningkatkan kinerja instalasi desalinasi6,7). Kualitas air produk desalinasi dengan proses MED dapat mencapai $1,960 \mathrm{ppm}^{8)}$. Guna memenuhi kriteria air spesifikasi PLTN, maka air produk proses desalinasi selanjutnya dimurnikan dengan penukar ion, dan untuk pendingin primer kemudian ditambah boron (dalam bentuk asam borat) yang berfungsi untuk menyerap netron sebagai kendali reaktivitas, lithium hidroksida dan hidrogen untuk pengendalian $\mathrm{pH}$ dan penghambat terjadinya korosi5).

Dalam instalasi desalinasi MED, pembentukan kerak pada permukaan perpindahan panas merupakan salah satu problem yang dapat mengurangi efektivitas perpindahan panas sehingga menurunkan kinerja instalasi dan efisiensi proses. Kerak didefinisikan sebagai deposit kristalin yang keras, yang terutama terdiri dari garamgaram inorganik, yang menempel pada permukaan perpindahan panas dan memerlukan metode fisika dan atau kimia untuk menghilangkannya ${ }^{9}$. Oleh karena itu pembentukan kerak pada instalasi desalinasi MED perlu dikaji, sehingga dapat ditentukan jenis penanganan yang tepat untuk kendali kerak tersebut.

Pembentukan kerak dalam instalasi desalinasi MED disebabkan oleh deposisi garam inorganik seperti kalsium karbonat, kalsium sulfat dan magnesium hidroksida pada permukaan penukar panas ${ }^{10,11}$. Pada pembentukan kerak kalsium sulfat, potensi pembentukan kerak dapat diperkirakan dengan menghitung Scaling Index (SI). Sedangkan potensi pembentukan kerak kalsium karbonat dapat diindasikan dengan Langelier Saturation Index (LSI). Kerak magnesium hidroksida dapat diperkirakan dengan menghitung hasil kali konsentrasi komponen.

Tujuan penulisan makalah ini adalah memperkirakan potensi pembentukan kerak dalam instalasi desalinasi MED, dengan air umpan dari Teluk Manggris, pulau Bangka. Hasil studi diharap dapat memberi masukan bagi pengambil kebijakan, guna menyongsong pembangunan PLTN di Indonesia.

\section{BAHAN DAN METODE}

\section{Metode}

Metode yang digunakan dalam studi adalah kajian literatur dan analisis dengan menghitung Scaling Index, Langelier Saturation Index dan hasil kali konsentrasi komponen. Dalam kajian ini, komponen instalasi desalinasi MED yang akan di bahas adalah evaporator. Dalam proses desalinasi MED, uap mengalir ke dalam pipa-pipa (tube) horizontal di dalam tiap tahapan evaporator dan air laut disemprotkan ke sisi luar tube. Uap yang mengalir di dalam tube akan mengembun, dan melepaskan panas latentnya ke lapisan film air laut yang terjadi di dinding sisi luar tube, sehingga lapisan film air laut itu sebagian mendidih dan menguap, sedangkan sisanya jatuh ke dasar evaporator dan disebut brine (konsentrat garam), seperti terlihat dalam Gambar 1. Kerak dapat terbentuk di luar tube sehingga perlu dianalisis potensi pembentukannya. 
Potensi Pembentukan Kerak pada Instalasi Desalinasi Nuklir MED dengan Air Umpan dari Teluk Manggaris (Siti Alimah, Djati W.Salimy)

\section{Bahan}

Bahan yang dapat digunakan sebagai tube adalah paduan $\mathrm{Cu} / \mathrm{Ni} 90 / 10$, Aluminium Brass, AIMgSi0.5 dan SS 1.4565. Perlu dilakukan kajian lebih lanjut untuk menentukan jenis bahan yang tepat.

\section{Potensi Pembentukan Kerak Pada Instalasi MED}

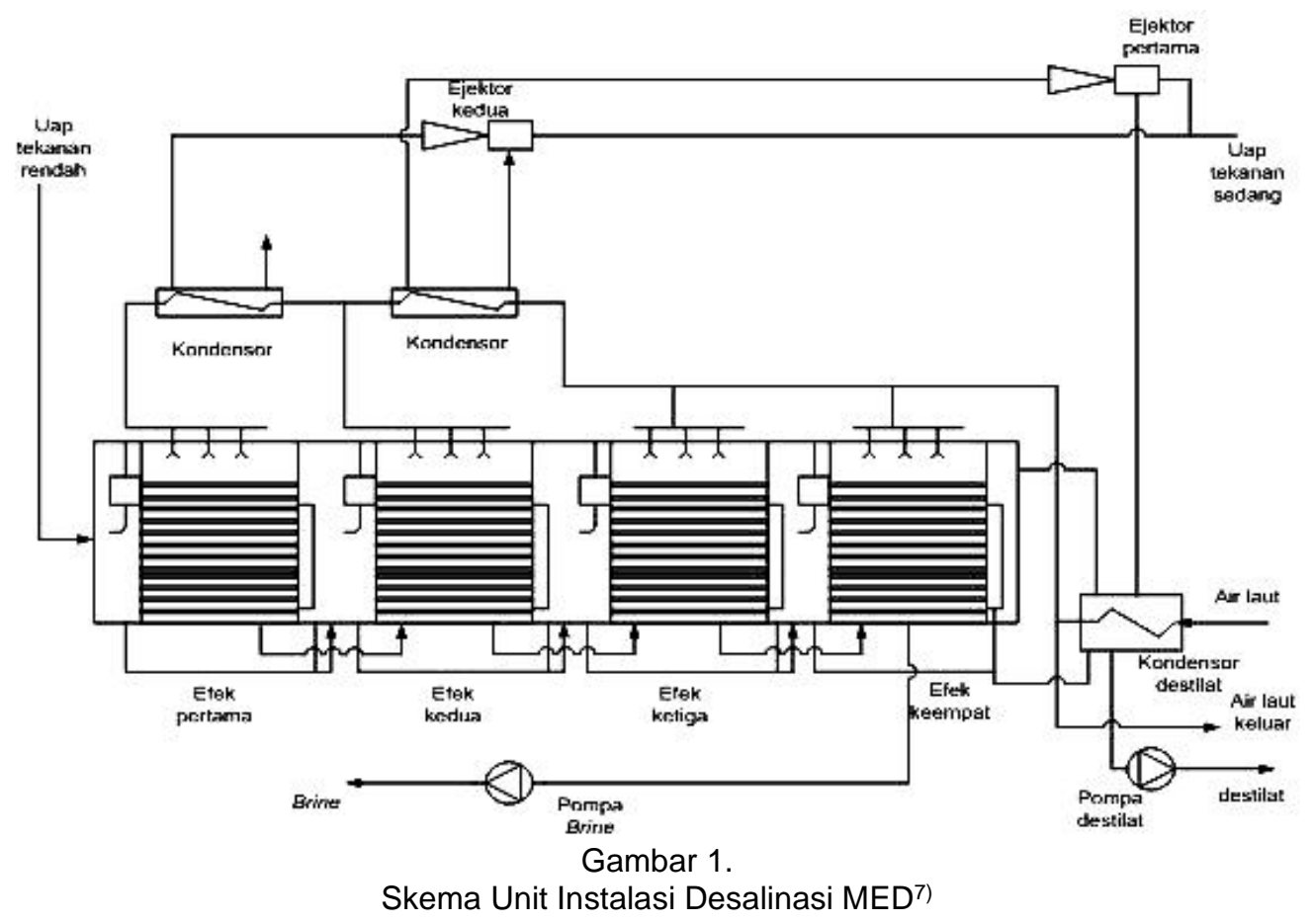

Kerak dalam instalasi desalinasi thermal seperti MED, merupakan salah satu faktor yang menurunkan kinerja. Untuk optimisasi proses operasi, maksimum temperatur brine adalah $70^{\circ} \mathrm{C}^{12)}$, sehingga secara teoritis kerak bukan problem yang besar pada desalinasi temperatur rendah. Namun dalam prakteknya, jika berbagai faktor perawatan tidak dilakukan, kerak dapat terjadi dalam instalasi ini.

Pembentukan kerak dalam instalasi desalinasi MED disebabkan oleh deposisi garam inorganik seperti kalsium karbonat, kalsium sulfat dan magnesium hidroksida. Kelarutan garam-garam tersebut menurun dengan peningkatan temperatur. Ketika batas kelarutan senyawa tersebut terlampaui, maka kerak akan terbentuk. Pembentukan kerak pada permukaan perpindahan panas akan mengurangi koeifisien perpindahan panas keseluruhan. Selanjutnya efisiensi menurun dan produksi air akan menurun.

Dalam alat distilasi multi efek (MED) dengan horisontal tube falling film evaporator, pengurangan atau pencegahan kerak adalah sukar karena kerak dibentuk pada sisi luar tube. Oleh karena itu metode pembersihan mekanik seperti sistem pembersihan dengan bola bukan merupakan teknik kontrol kerak yang efektif untuk MED. Untuk menentukan teknik kontrol kerak yang efektif maka perlu diketahui potensi pembentukan kerak.

\section{$\mathrm{Kerak} \mathrm{CaSO}_{4}$}

Kerak kalsium sulfat melekat keras, tidak larut dalam asam mineral dan beberapa pelarut umum lain. Kerak kalsium sulfat adalah hasil kristalisasi langsung gypsum $\left(\mathrm{CaSO}_{4} .2 \mathrm{H}_{2} \mathrm{O}\right)$, hemihidrat $\left(\mathrm{CaSO}_{4} .1 / 2 \mathrm{H}_{2} \mathrm{O}\right)$ dan anhidrat $\left(\mathrm{CaSO}_{4}\right)$ dari air laut, ketika batas kelarutan terlampaui. Hemihidrat $\left(\mathrm{CaSO}_{4} \cdot 1 / 2 \mathrm{H}_{2} \mathrm{O}\right)$ adalah metastabil dan diendapkan ketika air diuapkan pada temperatur di atas $100^{\circ} \mathrm{C}$. Fase laju transisi dan temperatur dalam sistem kalsium sulfat larutan diperlihatkan dalam Gambar 2. Di atas sekitar $42^{\circ} \mathrm{C}$, anhidrat stabil dibentuk, dan di bawah temperatur ini gypsum juga stabil10). 


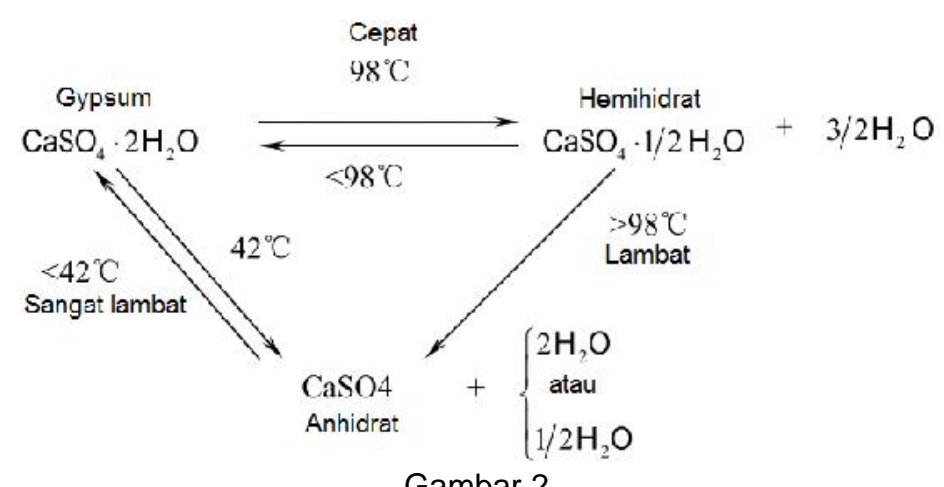

Gambar 2.

Fase Laju Transisi dan Temperatur dalam Sistem Kalsium Sulfat Larutan ${ }^{13)}$.

$\mathrm{Di}$ atas $98^{\circ} \mathrm{C}$, bentuk hemihidrat lebih stabil daripada gypsum, tapi kurang stabil dari anhidrat. Di atas $42^{\circ} \mathrm{C}$, nukleasi dari anhidrat, tidak spontan. Pertamakali, hemihidrat akan terbentuk, dan selanjutnya ditransformasi menjadi anhidrat perlahan-lahan. Kristal gypsum adalah monoklinik, hemihidrat heksagonal dan anhidrat orthorombik.

Kelarutan kalsium sulfat menurun dengan peningkatan temperatur. Dalam larutan garam yang mengandung ion-ion umum, kelarutan kalsium sulfat akan menurun. Namun dalam larutan dengan konsentrasi garam tinggi, efeknya adalah kebalikan. Beberapa studi memperlihatkan bahwa kelarutan semua garam kalsium sulfat meningkat dengan peningkatan konsentrasi $\mathrm{NaCl}$, dan mencapai maksimum antara 2-3 molal dan menurun pada tingkat garam lebih tinggi. Ion magnesiun cukup signifikan mempengaruhi kelarutan kalsium sulfat karena muatan densitas tinggi. Gypsum lebih larut dalam larutan magnesium klorida,daripada dalam larutan $\mathrm{NaCl}$.

Potensi pembentukan kerak kalsium sulfat dapat dihitung dengan persamaan berikut ${ }^{13)}$ :

$$
\mathrm{SI}\left(\mathrm{CaSO}_{4}\right)=\frac{\left[\mathrm{Ca}^{2+}\right]\left[\mathrm{SO}_{4}{ }^{2-}\right]}{\mathrm{Ksp}}
$$

dengan,

$$
\begin{array}{ll}
\mathrm{SI} & : \text { Indeks pengerakan } \\
{\left[\mathrm{Ca}^{2+}\right]} & : \text { Konsentrasi molar } \mathrm{Ca}^{2+} \\
{\left[\mathrm{SO}_{4}{ }^{2-}\right]} & : \text { Konsentrasi molar } \mathrm{SO}_{4}{ }^{2-} \\
\mathrm{Ksp} \mathrm{CaSO}_{4} & \left.: 2 \times 10^{-5} 14\right)
\end{array}
$$

Harga SI kurang dari 1 menandakan larutan kurang jenuh, sehingga kerak $\mathrm{CaSO}_{4}$ tidak akan terbentuk. SI lebih dari 1 menandakan larutan lewat jenuh, sehingga kerak akan terbentuk.

\section{Kerak $\mathrm{CaCO}_{3}$ dan $\mathrm{Mg}(\mathrm{OH})_{2}$}

Kerak alkali merupakan hasil interaksi antara produk dekomposisi dan hidrolisis dari ion bikarbonat dalam air laut dengan ion kalsium dan magnesium, sehingga menghasilkan $\mathrm{CaCO}_{3}$ dan $\mathrm{Mg}(\mathrm{OH})_{2}{ }_{2}^{15}$. Pada pemanasan air laut di atas temperatur $45^{\circ} \mathrm{C}$, bikarbonat akan terdekomposisi yang reaksinya adalah sebagai berikut ${ }^{16,17)}$ :

$$
2 \mathrm{HCO}_{3}{ }^{-}=\mathrm{CO}_{3}^{2-}+\mathrm{H}_{2} \mathrm{O}+\mathrm{CO}_{2}
$$

Ini akan menyebabkan pengendapan $\mathrm{CaCO}_{3}$, ketika batas kelarutan terlampaui ( $\mathrm{K}=4,7$ akan $\left.6,9 \times 10^{-9}\right)^{14)}$, dengan reaksi sebagai berikut :

$$
\mathrm{Ca}^{2+}+\mathrm{CO}_{3}^{2-}=\mathrm{CaCO}_{3}
$$

Pada temperatur yang lebih tinggi $\left(\geq 80^{\circ} \mathrm{C}\right)$, ion karbonat terhidrolisa menjadi $\mathrm{OH}^{-}$dengan reaksi sebagai berikut :

$$
\mathrm{CO}_{3}{ }^{2-}+\mathrm{H}_{2} \mathrm{O}=2 \mathrm{OH}^{-}+\mathrm{CO}_{2}
$$

Ion hidroksil akan menyebabkan terbentuknya $\mathrm{Mg}(\mathrm{OH})_{2}$ yang tidak larut $\left(\mathrm{K}=8,9 \times 10^{-12}\right)^{15)}$.

$$
\mathrm{Mg}^{2+}+2 \mathrm{OH}=\mathrm{Mg}(\mathrm{OH})_{2}
$$

Deposisi kalsium karbonat juga tergantung $\mathrm{pH}$. Kisaran $\mathrm{pH}$, dari distribusi jenis karbonat dalam air laut diperlihatkan dalam Gambar 3. Asam karbonat adalah dominan di bawah $\mathrm{pH}$ 6 , dan ion karbonat di atas $\mathrm{pH}$ 9. Di antara $\mathrm{pH} 6$ dan 9, air mengandung ion bikarbonat.

Parameter lain yang mempengaruhi pembentukan kerak adalah adanya gas-gas yang tidak terkondensasi yang disebabkan oleh kebocoran flange, man hole, nozel, dan lain-lain, yang menjadi bagian operasi evaporator, yang dapat menyebabkan pelepasan $\mathrm{CO}_{2}$ dari evaporasi. Pelepasan $\mathrm{CO}_{2}$ dari evaporasi larutan garam, akan mempengaruhi konsentrasi ion-ion 
Potensi Pembentukan Kerak pada Instalasi Desalinasi Nuklir MED dengan Air Umpan dari Teluk Manggaris (Siti Alimah, Djati W.Salimy)

bikarbonat, $\mathrm{CO}_{2}, \mathrm{H}^{+}$dan $\mathrm{OH}^{-}$, sehingga mempengaruhi pembentukan kerak ${ }^{16)}$.

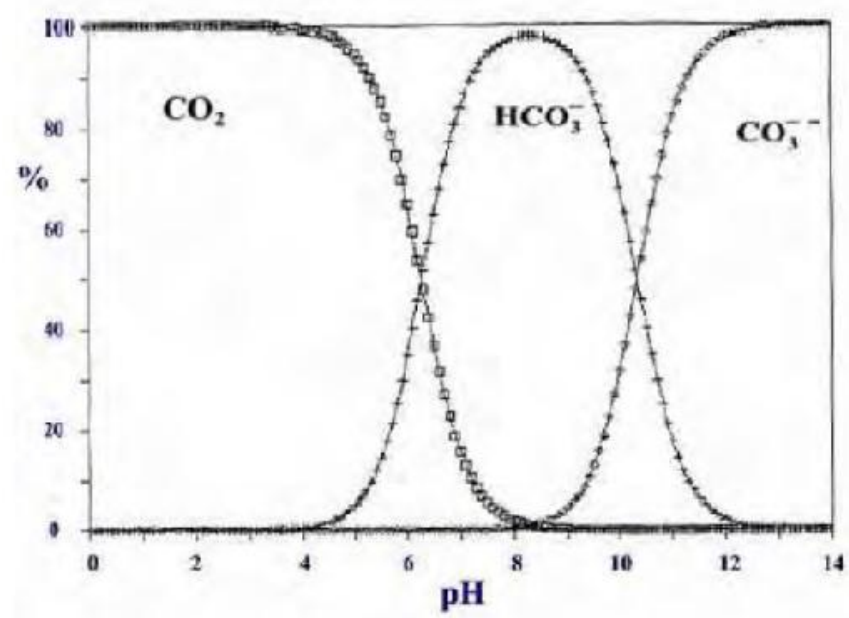

Gambar 3.

Distribusi Jenis Karbonat pada $25^{\circ} \mathrm{C}^{18}$ ).

Salah satu persamaan yang dapat mengindikasikan terbentuknya kerak $\mathrm{CaCO}_{3}$ adalah Langelier Saturation Index (LSI). LSI merupakan indeks kualitatif yang mengindikasikan suatu larutan jenuh atau tidak jenuh dengan $\mathrm{CaCO}_{3}{ }^{19)}$. LSI juga dapat mengindikasikan kecenderungan korosifitas $^{20)}$. LSI didefinisikan sebagai :

LSI
dengan

$\mathrm{pH}$ : harga $\mathrm{pH}$ sebenarnya

pHs : harga $\mathrm{pH}$ dari $\mathrm{CaCO}_{3}$ jenuh

$$
p H s=p K_{2}-p K s p+p T A+p\left[\mathrm{Ca}^{2+}\right]
$$

dengan, :
$\mathrm{K}_{2}$ : Konstanta disosiasi ke dua asam karbonat
Ksp : Konstanta kelarutan kalsium karbonat
TA : Total alkalinitas
$\left[\mathrm{Ca}^{2+}\right]$ : Konsentrasi kalsium
$\mathrm{p}:$ : negatif logaritme

Jika harga LSI negatif ( $\mathrm{pH}<\mathrm{pHs}$ ), air tidak jenuh dengan $\mathrm{CaCO}_{3}$ dan air potensial korosif, jika LSI <-0,521). Sebaliknya, jika LSI positif ( $\mathrm{pH}>\mathrm{pHs}$ ), air super jenuh dengan $\mathrm{CaCO}_{3}$, dan air berpotensi membentuk kerak. Air jenuh mempunyai harga $\mathrm{LSI}$ nol $(\mathrm{pH}=$ $\mathrm{pHs}$ ).

Selain $\mathrm{pH}$, temperatur dan pelepasan $\mathrm{CO}_{2}$ (dalam kasus kerak alkali), faktor utama yang mempengaruhi pembentukan kerak adalah konsentrasi ion-ion $\mathrm{HCO}_{3}^{-}$, total alkalinitas, $\mathrm{Ca}^{2+}, \mathrm{Mg}^{2+}$ dan $\mathrm{SO}_{4}{ }^{2-}$ yang ada dalam air umpan. Pada studi ini akan dianalisis potensi pembentukan kerak, dengan air umpan dari Teluk Manggris, Pulau Bangka, yang hasil analisisnya diperlihatkan pada Tabel 1.

Tabel 1.

Hasil Analisis Air Laut Teluk Manggris ${ }^{1)}$.

\begin{tabular}{|c|c|c|c|}
\hline No. & Parameter & Satuan & Hasil \\
\hline 1. & $\mathrm{pH}$ & - & 6,85 \\
\hline 2. & Konduktivitas & $\mu \mathrm{S} / \mathrm{cm}$ & 43,5 \\
\hline 3. & $\begin{array}{l}\text { Total alkalinitas sbg } \\
\mathrm{CaCO}_{3}\end{array}$ & ppm & 200,85 \\
\hline 4. & TDS & ppm & 32804,00 \\
\hline 5. & Padatan tersuspensi & ppm & 48,20 \\
\hline 6. & Kalsium (Ca) & ppm & 433,74 \\
\hline 7. & Magnesium (Mg) & ppm & 1938,63 \\
\hline 8. & Sodium $(\mathrm{Na})$ & ppm & 10992,96 \\
\hline 9. & Potasium (K) & ppm & 327,87 \\
\hline 10. & Klorida (Cl) & ppm & 16820,07 \\
\hline 11. & Sulfat $\left(\mathrm{SO}_{4}\right)$ & ppm & 3898,92 \\
\hline 12. & Bikarbonat & $\mathrm{ppm}$ & 244,60 \\
\hline 13. & $\mathrm{SiO}_{2}$ & ppm & 1,34 \\
\hline 14. & $\mathrm{~F}$ & ppm & $\mathrm{ttd}$ \\
\hline
\end{tabular}

\section{HASIL DAN PEMBAHASAN}

Sebagian besar evaporator MED untuk desalinasi air laut menggunakan prinsip seperti diperlihatkan dalam Gambar 4 . Teknologi untuk mendispersikan dan menguapkan sebagian air laut di bagian luar tube adalah teknologi yang paling umum ${ }^{22}$. Sistem distribusi yang bertugas mendistribusikan air umpan terletak pada puncak bundel tube horisontal. Air umpan mengalir dari tube row ke tube row, dan sebagian diuapkan. Rasio air umpan berbanding distilat $3: 1$, yang maksudnya 33,3\% air umpan diuapkan. Problem utama dalam desain evaporator tersebut adalah menjamin aliran yang cukup dari air umpan 
pada tube. Oleh karena itu, mengontrol pembentukan kerak di luar tube sangat

diperlukan, untuk menjaga aliran air umpan.

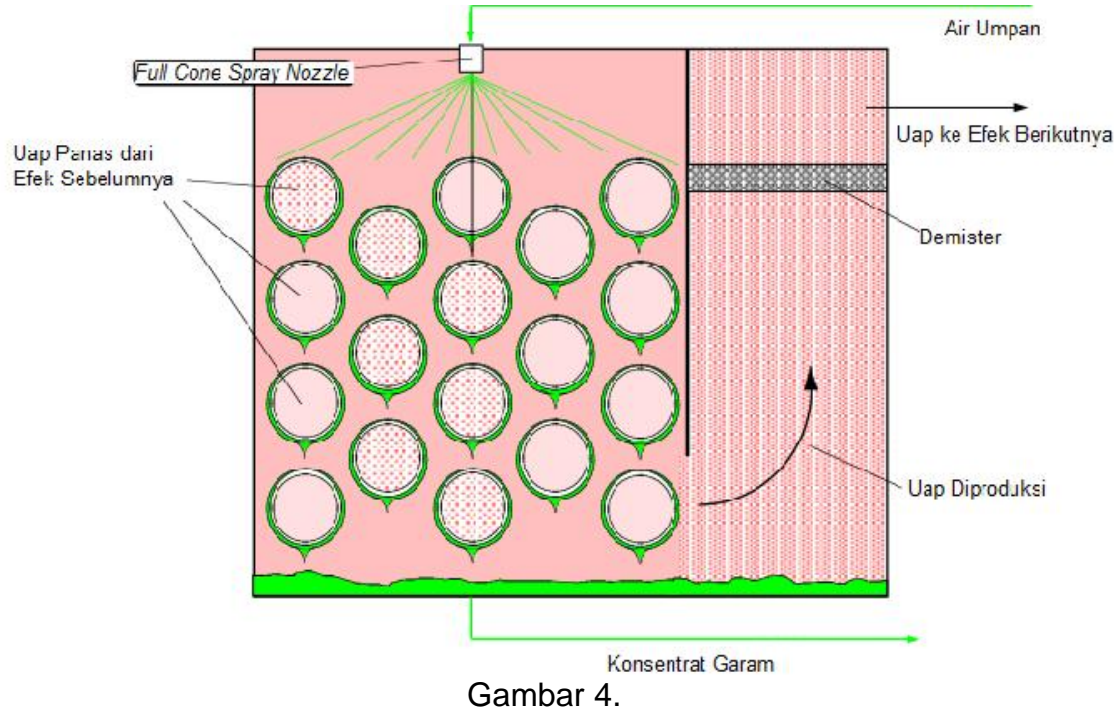

Prinsip Kerja Horisontal Tube(Falling Film) Evaporator ${ }^{23) .}$

Terdapat dua kemungkinan fenomena yang dapat menyebabkan pembentukan kerak dalam falling film evaporator yaitu kelarutan terbalik dari hardness salt dengan temperatur dan pengendapan garam pada tube, ketika aliran air laut menurun sampai di bawah aliran desain minimum ${ }^{24)}$.

Air laut adalah larutan elektrolit campuran, dengan komposisi kimia yang bervariasi. Air laut mempunyai karakteristik dengan salinitas tinggi dan bervariasi tergantung lokasi. Dari hasil analisis air laut yang diambil dari Teluk Manggris, pulau Bangka, seperti terlihat dalam Tabel 1, akan dianalisis kemungkinan pembentukan kerak.

Potensi pembentukan kerak $\mathrm{CaSO}_{4}$ dapat dianalisis sbb:

$$
\mathrm{SI}\left(\mathrm{CaSO}_{4}\right)=\frac{\left[\mathrm{Ca}^{2+}\right]\left[\mathrm{SO}_{4}{ }^{2-}\right]}{\mathrm{Ksp}}
$$

Kapasitas produk desalinasi $90.000 \mathrm{~m}^{3} / \mathrm{hari}=$ $3.750 \mathrm{~m}^{3} / \mathrm{jam}$ dan densitas air laut 1030 $\mathrm{kg} / \mathrm{m}^{3}{ }^{25}$. Penguapan di evaporator diasumsi $40 \%$ agar beban panas yang dibutuhkan tidak terlalu besar sehingga menjaga alat, maka jumlah aliran air umpan:

$$
\frac{100}{4} \times 3750 \frac{\mathrm{m}^{3}}{\mathrm{jam}}=9375 \mathrm{~m}^{3} / \mathrm{jam}
$$

Massa air laut yang dimasukkan ke evaporator $=$

jumlah aliran air umpan $\mathrm{x}$ densitas

$$
=3750 \frac{\mathrm{m}^{3}}{\mathrm{jam}} \times 1030 \frac{\mathrm{kg}}{\mathrm{m}^{3}}=9656250 \mathrm{~kg} / \mathrm{jam}
$$

Perhitungan massa tiap komponen diperlihatkan dalam Tabel 2.

\begin{tabular}{|c|c|c|c|}
\hline No & Parameter & $\begin{array}{c}\% \\
\text { massa }\end{array}$ & $\begin{array}{l}\text { Massa, } \\
\text { kg/jam }\end{array}$ \\
\hline 1 & $\mathrm{pH}$ & & \\
\hline 2 & $\begin{array}{l}\text { Konduktivitas } \\
\text { Total }\end{array}$ & & \\
\hline 3 & $\begin{array}{l}\text { alkalinitas sbg } \\
\mathrm{CaCO}_{3}\end{array}$ & 0,0201 & $1.939,46$ \\
\hline 4 & TDS & 3,2804 & $316.763,63$ \\
\hline 5 & $\begin{array}{l}\text { Padatan } \\
\text { tersuspensi }\end{array}$ & 0,0048 & 465,43 \\
\hline 6 & Kalsium (Ca) & 0,0434 & $4.188,30$ \\
\hline 7 & $\begin{array}{l}\text { Magnesium } \\
(\mathrm{Mg})\end{array}$ & 0,1939 & $18.719,90$ \\
\hline 8 & Sodium (Na) & 1,0993 & $106.150,77$ \\
\hline 9 & Potasium (K) & 0,0328 & $3.165,99$ \\
\hline 10 & Klorida (Cl) & 1,6820 & $162.418,80$ \\
\hline 11 & Sulfat $\left(\mathrm{SO}_{4}\right)$ & 0,3899 & $37.648,95$ \\
\hline 12 & Bikarbonat & 0,0245 & $2.361,92$ \\
\hline 13 & $\mathrm{SiO}_{2}$ & 0,0001 & 12,94 \\
\hline 14 & $\mathrm{~F}$ & & \\
\hline 15 & $\mathrm{H} 2 \mathrm{O}$ & 96,5294 & $9.321 .117,0$ \\
\hline \multicolumn{2}{|c|}{ Jumlah } & 100,000 & $9.656 .250,0$ \\
\hline
\end{tabular}

Tabel 2.

Massa Tiap Komponen

$$
\begin{aligned}
\mathrm{SI}\left(\mathrm{CaSO}_{4}\right) & =\frac{\left[\mathrm{Ca}^{2+}\right]\left[\mathrm{SO}_{4}{ }^{2-}\right]}{K s p}=\frac{0,0112 \times 0,0418}{2.10^{-5}} \\
& =23,408
\end{aligned}
$$


Potensi Pembentukan Kerak pada Instalasi Desalinasi Nuklir MED dengan Air Umpan dari Teluk Manggaris (Siti Alimah, Djati W.Salimy)

Perhitungan konsentrasi tiap komponen

diperlihatkan dalam Tabel 3.

Tabel 3.

Konsentrasi Tiap Komponen

\begin{tabular}{|c|c|c|c|}
\hline No & Parameter & $\begin{array}{c}\text { Mol, } \\
\mathrm{kmol} / \mathrm{jam}\end{array}$ & $\begin{array}{c}\text { Konsentrasi } \\
\mathrm{kmol} / \mathrm{m}^{3}\end{array}$ \\
\hline 1 & $\mathrm{pH}$ & & \\
\hline 2 & Konduktivitas & & \\
\hline & Total alkalinitas sbg & & \\
\hline 3 & $\mathrm{CaCO}_{3}$ & & \\
\hline 4 & TDS & & \\
\hline 5 & Padatan tersuspensi & & \\
\hline 6 & Kalsium (Ca) & 104,71 & 0,0112 \\
\hline 7 & Magnesium (Mg) & 780,00 & 0,0832 \\
\hline 8 & Sodium (Na) & $4.615,25$ & 0,4923 \\
\hline 9 & Potasium (K) & 81,18 & 0,0087 \\
\hline 10 & Klorida $(\mathrm{Cl})$ & $4.575,18$ & 0,4880 \\
\hline 11 & Sulfat $\left(\mathrm{SO}_{4}\right)$ & 392,18 & 0,0418 \\
\hline 12 & Bikarbonat & 38,72 & 0,0041 \\
\hline 13 & $\mathrm{SiO}_{2}$ & 0,22 & 0,0000 \\
\hline 14 & $\mathrm{~F}$ & - & \\
\hline 15 & $\mathrm{H} 2 \mathrm{O}$ & $517.839,83$ & \\
\hline
\end{tabular}

Karena $\mathrm{SI}>1$, maka larutan lewat jenuh $\left[\mathrm{Mg}^{2+}\right]=0,0832 \mathrm{kmol} / \mathrm{m}^{3}$

sehingga kerak $\mathrm{CaSO}_{4}$ akan terbentuk.

Jika dilihat dari tingkat kejenuhan :

$\left[\mathrm{Ca}^{2+}\right] \cdot\left[\mathrm{SO}_{4}{ }^{2-}\right]=0,0112 \cdot 0,0418=4,6722 \cdot 10^{-4}$

$\mathrm{Ksp} \mathrm{CaSO}_{4}=2 \cdot 10^{-5}$

Sehingga hasil kali konsentrasi > Ksp, maka terbukti juga kalau larutan lewat jenuh.

Potensi pembentukan kerak $\mathrm{CaCO}_{3}$ diprediksi dengan menentukan nilai LSI.

$\mathrm{Ca}^{2+}+2 \mathrm{HCO}_{3}^{-} \rightarrow \mathrm{CaCO}_{3}+\mathrm{CO}_{2}+\mathrm{H}_{2} \mathrm{O}$

$\mathrm{K}_{2}=5,6 \cdot 10^{-11}$, maka $\mathrm{pK}_{2}=10,25$.

$\mathrm{Ksp}=3,8 \cdot 10^{-9}$, maka pKsp $=8,42$

$\left[\mathrm{OH}^{-}\right]=2 \times\left[\mathrm{Mg}^{2+}\right]=2 \times 0,0832$ $=0,1664 \mathrm{kmol} / \mathrm{m}^{3}$

Hasil kali konsentrasi komponen :

$\mathrm{Q}=\left[\mathrm{Mg}^{2+}\right] \times\left[\mathrm{OH}^{-}\right]^{2}=(0,0832) \times(0,1664)^{2}$

$=2,3037 \cdot 10^{-3}$

$\mathrm{Ksp} \mathrm{Mg}(\mathrm{OH})_{2}=8,9 \times 10^{-12}$

Karena $\mathrm{Q}>\mathrm{Ksp}$, maka $\mathrm{Mg}(\mathrm{OH})_{2}$ mengendap, sehingga potensial membentuk kerak.

$\mathrm{TA}=200,85 \mathrm{ppm}=2,0085 \cdot 10^{-4}$, maka

pTA $=3,70$

$\left[\mathrm{Ca}^{2+}\right]=0,0112 \mathrm{kmol} / \mathrm{m}^{3}$, maka $\mathrm{p}\left[\mathrm{Ca}^{2+}\right]=1,95$

Sehingga :

$\mathrm{pHs}=\mathrm{pK}_{2}-\mathrm{pKsp}+\mathrm{pTA}+\mathrm{p}\left[\mathrm{Ca}^{2+}\right]$

$=10,25-8,42+3,70+1,95$

$=7,48$

LSI $=\mathrm{pH}-\mathrm{pHs}$

$=6,85-7,48$

$=-0,63$

Diperoleh LSI bernilai negatif $(\mathrm{pH}<\mathrm{pHs})$ maka air tidak jenuh dengan $\mathrm{CaCO}_{3}$ dan air potensial korosi.

Potensi pembentukan kerak $\mathrm{Mg}(\mathrm{OH})_{2}$ diprediksi dengan menentukan hasil kali konsentrasi komponen.

\section{SIMPULAN}

Dari hasil analisis disimpulkan bahwa dalam instalasi desalinasi nuklir proses MED dengan air umpan dari Teluk Manggris, dengan kapasitas $90.000 \mathrm{~m}^{3} /$ hari berpotensi terbentuk kerak. Hasil perhitungan menunjukkan harga indeks pengerakan $\mathrm{CaSO}_{4}$ sebesar 23,408, yang mengindikasikan bahwa ada potensi pembentukan kerak oleh $\mathrm{CaSO}_{4}$. Potensi timbulnya kerak $\mathrm{CaCO}_{3}$ tidak ada, karena diperoleh harga LSI negatif dengan nilai $-0,63$. Namun air potensial bersifat korosif sehingga pertimbangan dalam pemilihan bahan alat perlu dilakukan. Selain itu juga terdapat potensi terbentuknya kerak $\mathrm{Mg}(\mathrm{OH})_{2}$ yang ditunjukkan oleh lebih besarnya harga hasil kali konsentrasi komponen dari pada Ksp. 


\section{UCAPAN TERIMAKASIH}

Penulis mengucapkan terima kasih kepada Ir. Sriyana, MT., yang telah berkenan memberi arahan dan masukan dalam penulisan makalah ini.

\section{DAFTAR PUSTAKA}

1. HENI SUSIATI, dkk., Studi Rona Awal Lingkungan Pada Tahap Pra-Survei di Dua Daerah Interes Untuk PLTN di Pulau Bangka, Prosiding Seminar Nasional Pengembangan Energi Nuklir IV, PPEN, BATAN, 2011.

2. ISHIGURE K, et. al., Hand Book Kimia Air Reaktor, Corona -sha, Japan, 2000.

3. Erlan Dewita, dkk., Optimasi Desain Desalinasi Nuklir menggunakan Konsep Zero Discharge Desalination (ZDD), Program Insentif Kegiatan Riset Peningkatan Kemampuan Peneliti dan Perekayasa (PKPP) Litbang Iptek Tahun 2012.

4. IAEA, Status of Design Concepts of Nuclear Desalination Plants, TECDOC1326, IAEA, Vienna, November 2002.

5. Siti Alimah, Studi Proses Desalinasi Untuk PLTN Jenis PWR, Presentasi IImiah di PPEN, BATAN, 28 Mei 2008.

6. Siti Alimah, dkk, Aspek Tekno-Ekonomi Penggunaan TVC Pada Desalinasi MED Untuk Pasokan Air Bersih PLTN, Prosiding Seminar Nasional ke-15 Teknologi dan Keselamatan PLTN, serta Fasilitas Nuklir, 17 Oktober 2009.

7. I.S. Park, et.all., Design and Application of Thermal Vapor Compressor for MultiEffect Desalination Plant, Desalination 182, 21 Februari 2005

8. IAEA, Introduction of Nuclear Desalination, Technical Reports Series No.400, IAEA, Vienna, 2000.

9. Al-Shammiri M.A., et.all., Scaling Potential of a Doha Beachwell at Different Operating Temperatures, Kuwait J. Science Engineering 35, 2008.

10.Wildebrant, C., Effect of Process Parameters and Antiscalant on Scale Formation in Horizontal Tube Falling Film Evaporator, Desalination 204, 2007.

11.AL-HAMZAH, A.A., et.all., A Comparative Study of Novel AScale Inhibitors with Commercial Scale Inhibitor Used in Seawater Desalination, Desalination 359, 2015.
12. Ophir A, et.all., Advanced MED Process for Most Economical Sea Water Desalination, Desalination 182, 2005.

13.Yuan Wang, Composite Fouling of Calsium Sulfate and Calsium Carbonate in a Dynamic Seawater RO Unit, Thesis Master of Science, Australia, December, 2005.

14.http://www.wiredchemist.com/chemistry/d ata/solubility-product-constants, diakses, Juni 2015.

15.Sam El Din, A.M., et.all., Scale Formation in Flash Chamber of High Temperature MSF Distiller, Desalination 177, 2005.

16. Siti Alimah, Fenomena Kerak Dalam Desalinasi dengan MSF, Jurnal Pengembangan Energi Nuklir, Vol. 8, No.1, Juni 2006.

17.Suresh Patel, et.all, New Antifoulant for Deposit Kontrol in MSF and MED Plant, Desalination 124, 1999.

18.Al-Rawajfeh, A.A., $\mathrm{CO}_{2}$ Release in Multiple-Effect Distiller Controlled by Mass Transfer With Chemical Reaction, Desalination 156, 2003.

19.Al-Rawajfeh, A.A, et all., Scaling in Multiple-Effect Distiller : The Role of $\mathrm{CO}_{2}$ Release, Desalination 182,2005.

20. Faizur Rahman, et.all, Scale Formation and Control in Thermal Desalination Systems, The Science and Technology of Industrial Water Treatment, February, 2009.

21.https://smk3ae.wordpress.com/2008/07/1 5/korosifitas-kerak-dan-perhitungannya/, diakses Juni 2015.

22.Paul Schausberger, et.all., Heat Transfer in Horizontal Falling Film Evaporators, IDA World Congress, November 7-12, 2009.

23. Greffart, R., Effect of Scaling on Design and Operation of Thermal Seawater Desalination Plants, Scaling Colour E. Doc, Jerman, September, 2002.

24.Budhiraja, P., et.all., Studies of Scale Formation and Optimization of Antiscalant Dosing in Multi-Effect Thermal Desalination Units, Desalination 220, 2008.

25.Beicher, Robert J., Physics for Scientists and Engineers, Orlando : Saunders College, 2000. 